\title{
NEW EVIDENCES TO UNDERSTAND THE BELL BEAKER CULTURE IN THE MAŁOPOLSKA UPLAND
}

\author{
PAWE七 JAROSZ - A NITA SZCZEPANEK - ELŻBIETA H A DUCH
}

\begin{abstract}
The aim of the article is to present the new AMS ${ }^{14} \mathrm{C}$ dating and analysis of strontium, carbon and nitrogen isotopes acquired for graves 2 and 5 from Beradź, Sandomierz county. In both graves there were buried individuals at senilis age: in the grave $2-a$ female and in the grave 5 - a male. The newly acquired dates indicate that graves from southeastern Poland could be synchronized with the older or classical stage of the Bell Beaker culture development within its eastern province restricted to the range of about 2400-2200 BC. Analysis of carbon and nitrogen isotopes allowed to state that the paleodiet of buried individuals was typical for terrestrial environments based on C3 plants supplemented with animal protein. Results of strontium isotopic signatures showed that a female was local, while a male spent his childhood somewhere else but probably within Małopolska Upland areas.
\end{abstract}

Keywords: Małopolska Upland, Bell Beaker culture, Final Neolithic, ${ }^{14} \mathrm{C}$ chronology, isotopic analyses.

Discovers of the Bell Beaker culture graves in southeastern Poland or more exactly in the Małoposka Upland are exceptional events. There have been known 10 sites with graves of this culture so far (Fig. 1; Budziszewski/Włodarczak 2010; Rudnicki/Włodarczak 2010). Some osteological materials from these sites have been currently under interdisciplinary, i. e. isotopic, genetic and chronometric analysis (Linderholm et al. 2020; Olalde et al. 2018; Włodarczak/Kowalewska-Marszatek 1998). As a part of the NCN project (2016/20/S/HS3/00307),
${ }^{14} \mathrm{C}$ dating and analysis of strontium $\left({ }^{87} \mathrm{Sr} /{ }^{86} \mathrm{Sr}\right)$, carbon $\left(\delta^{13} \mathrm{C}\right)$ and nitrogen $\left(\delta^{15} \mathrm{~N}\right)$ isotopes for graves 2 and 5 from Beradź, Sandomierz county have been performed. These graves formed a small cemetery of three burials (Nos. 1, 2,5) located at the edge of the loess plateau rising above the valley of the Kozinka River. The excavations were conducted in 1928 by K. Salewicz (Żurowski 1932, 124) and then they were described in terms of the funeral rite and equipment details by J. Budziszewski and P. Włodarczak (2010).

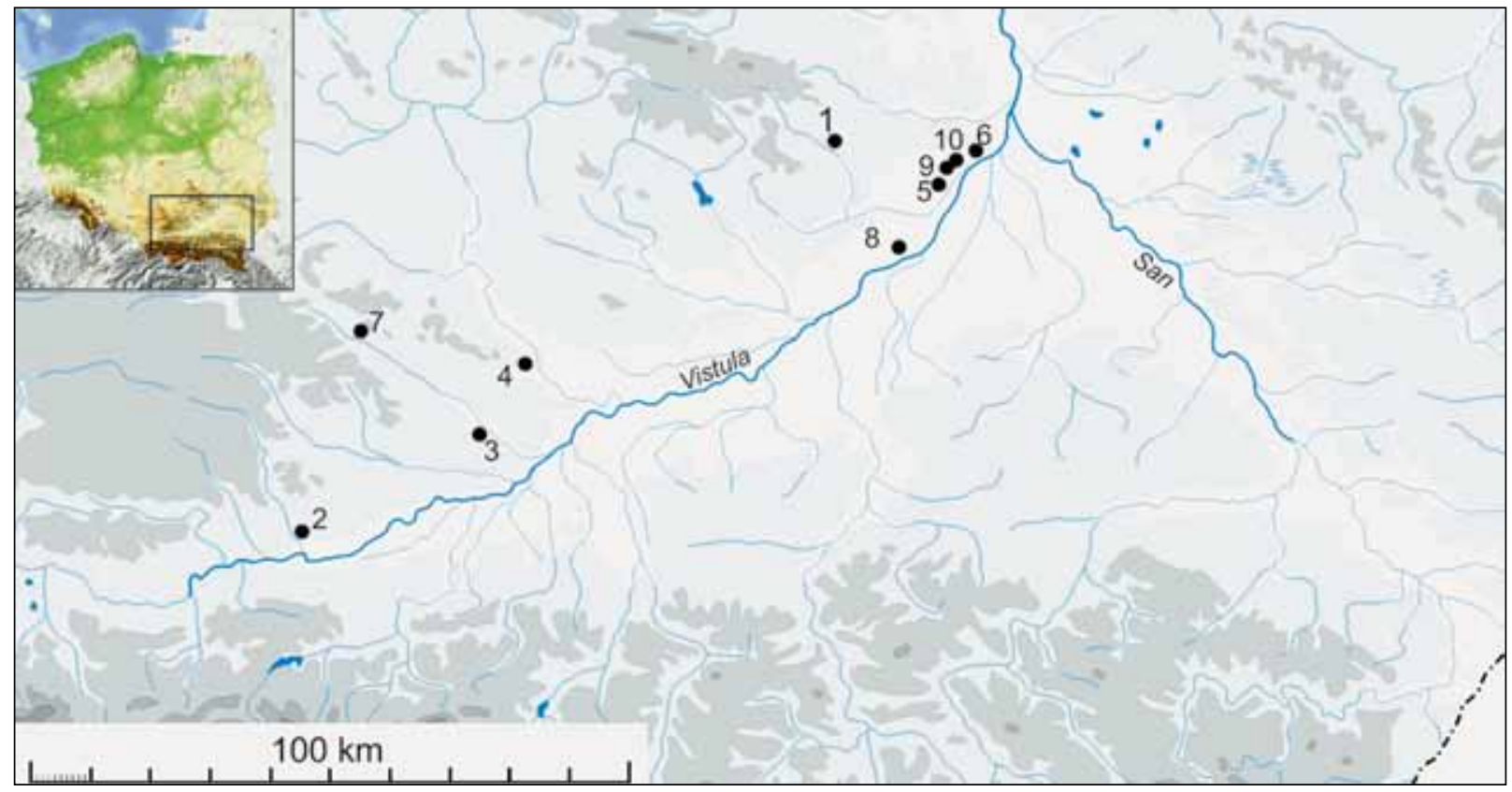

Fig. 1. Location of the Bell Beaker Culture grave sites in the Małopolska Upland. 1-Beradź, site 1; 2 -Kraków-Krzesławice, site 41;3-Odonów, site 4 (unpublished); 4 - Pełczyska, site 6; 5 -Samborzec, site 1; 6-Sandomierz, site 1 ('Wzgórze Zawichojskie'); 7 - Święcice, site 7; 8 - Świniary Stare, site 1; 9 - Złota, site 2 ('Grodzisko II'); 10 - Złota, site 3 ('Nad Wawrem'). 

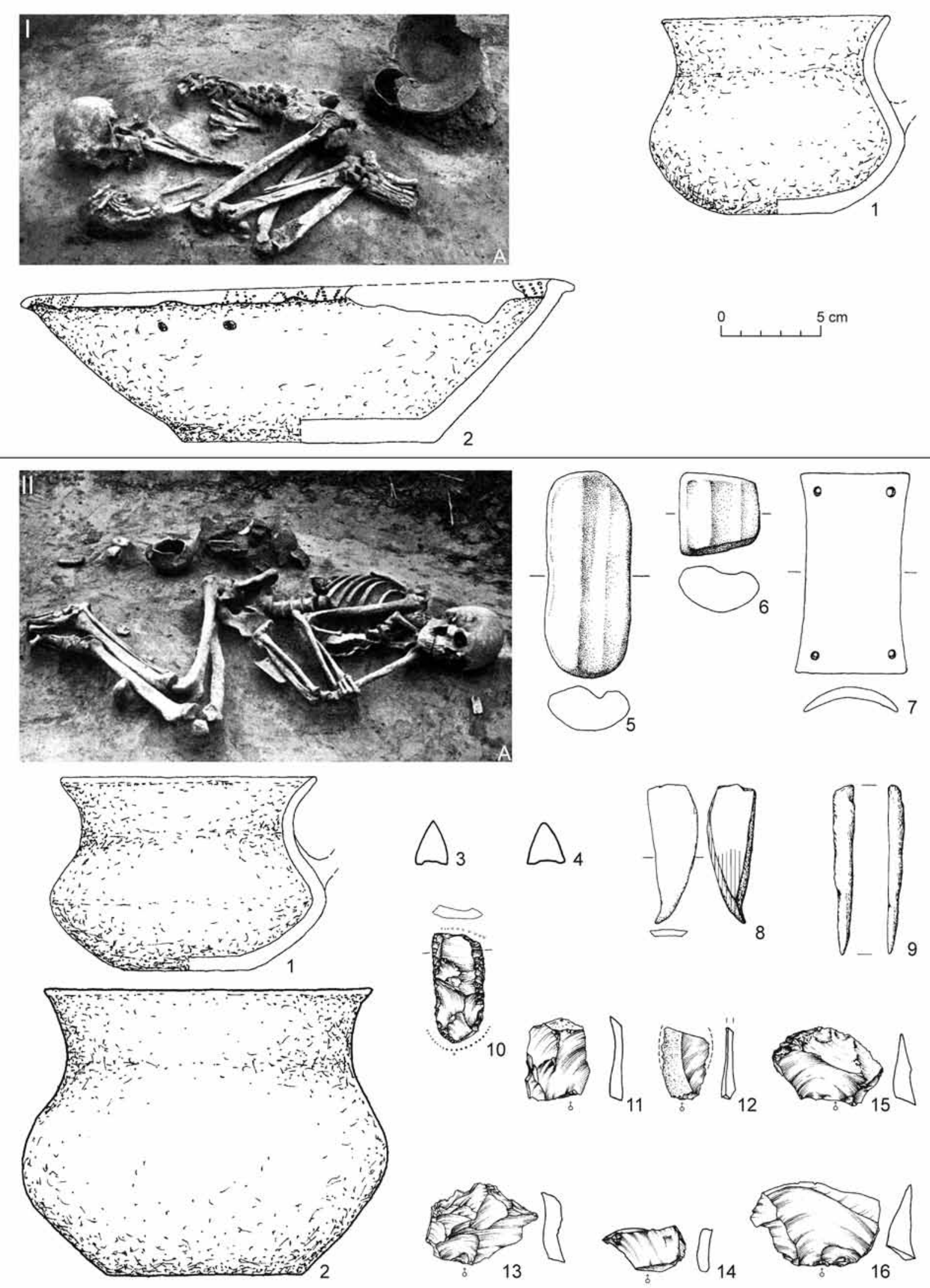

Fig. 2. Beradź, Sandomierz county, site 1. I - grave 2: A - photo of the grave; 1, 2 - grave inventory; II - grave 5: A - photo of the grave; 1-16 - grave inventory (after Budziszewski/Włodarczak 2010). 
A female at senilis age was buried (Haduch 2010) in grave 2. She was placed on the right side with strongly bent legs and the head facing to the south. Grave goods were gathered at the height of the deceased's legs and consisted of a bowl and a cup with a damaged ear (Fig. 2: I1, I2). In grave 5 there was discovered a male at senilis age, placed in a contracted position on his left side with the head to the north. Most of the equipment was located behind the deceased at the hip level. These were two vessels (Fig. 2: II1, II2), a bone awl (Fig. 2: II9), a boar tool (Fig. 2: II8), two polishing stones, likely used for arrowheads (Fig. 2: II5, II6) and flint chips (Fig. 2: II11-II16). Two flint arrowheads were placed nearby (Fig. 2: II3, II4). The archery wristguard was located at the left forearm (Fig. 2: II7) and the flint striker (Fig. 2: II10) at forehead level.
Graves 2 and 5 from Beradź contained 4 vessels: a beaker (grave 5), cups with damaged ears (grave 2 and 5) and a bowl (grave 5), which was the only one to have a decoration on the thickened rim of the vessel. This type of decoration is relatively common at Moravian sites of Bell Beaker culture, e. g. at the cemetery in Blažovice, site II and Kobylnice, site I (Dvořák 1992, pl. 37: 39; 52: B4). In grave 5, archery equipment consisting of a stone archery wristguard (according to the classification of E. Sangmeister 1974), flint arrowheads and polishing stones was discovered. Such artefacts are usually found only in rich, male burials. In the eastern province of this culture, we know such assemblages (Ryan et al. 2018, fig. 1; tab. 1; 2). In the Małopolska Upland, separate elements of this equipment are known from the graves at Świnary Stare, grave 4/1; Złota 'Nad

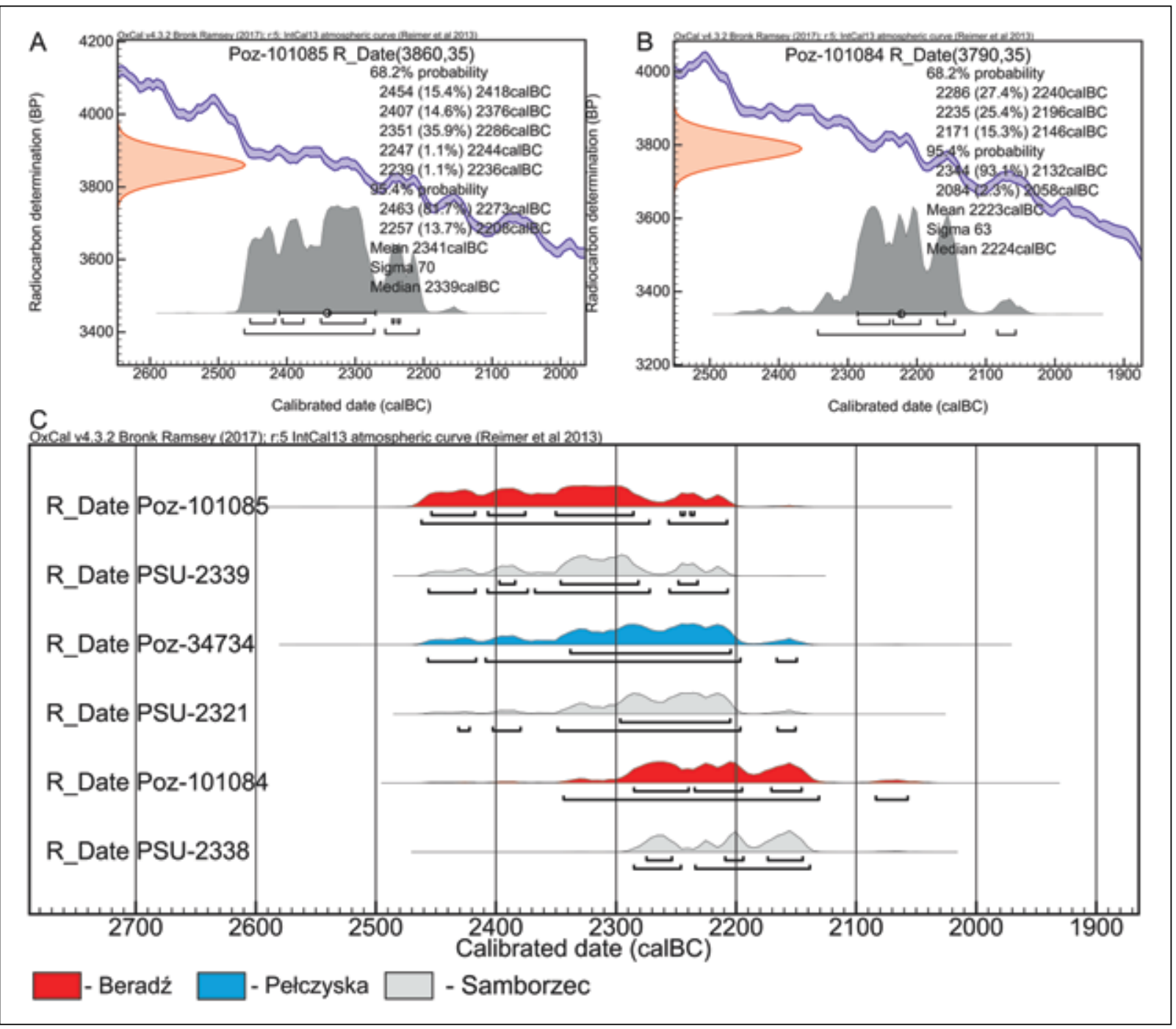

Fig. 3. Diagram with AMS dates calibration of the Bell Beaker culture from Beradź, site 1, grave 2 (A) and grave 5 (B). C - calibrated AMS dates from the Małopolska (after Rudnicki/Włodarczak 2010; Olalde et al. 2018). 
Table 1. Results of isotopic analysis: ${ }^{14} \mathrm{C},{ }^{87} \mathrm{Sr} /{ }^{86} \mathrm{Sr}, \delta^{13} \mathrm{C}$ and $\delta^{15} \mathrm{~N}\left({ }^{*}-\right.$ Rudnicki/Wtodarczak 2010; ${ }^{* *}$ - Olalde et al. 2018; ${ }^{* * *}$ - Linderholm et al. 2018).

\begin{tabular}{|c|c|c|c|c|c|c|c|c|}
\hline Site & $\begin{array}{c}\text { Feature/ } \\
\text { grave }\end{array}$ & Lab. No. & BP & $68,2 \%$ & $95,4 \%$ & $\delta^{13} C_{\text {coll }}$ & $\delta^{15} \mathrm{~N}_{\text {coll }}$ & ${ }^{87} \mathrm{Sr} /{ }^{86} \mathrm{Sr}$ \\
\hline Beradź, site 1 & 2 & Poz-101085 & $3860 \pm 35$ & $2454-2236$ & $2463-2273$ & -20 & 10.2 & $0.709665 \pm 10$ \\
\hline Beradź, site 1 & 5 & Poz-101084 & $3790 \pm 35$ & $2286-2146$ & 2344-2058 & -20.1 & 10.6 & $0.708667 \pm 12$ \\
\hline $\begin{array}{l}\text { Pełczyska, } \\
\text { site } 6\end{array}$ & $12 / 2004$ & Poz-34734* & $3830 \pm 35$ & 2339-2205 & $2457-2417$ & - & - & $0.709384 \pm 16^{\star * *}$ \\
\hline $\begin{array}{l}\text { Samborzec, } \\
\text { site } 1\end{array}$ & 1 & PSUAMS-2338** & $3780 \pm 20$ & $2275-2145$ & $2286-2139$ & - & - & - \\
\hline $\begin{array}{l}\text { Samborzec, } \\
\text { site } 1\end{array}$ & 7 & PSUAMS-2321** & $3825 \pm 25$ & $2297-2206$ & 2432-2151 & - & - & - \\
\hline $\begin{array}{l}\text { Samborzec, } \\
\text { site } 1\end{array}$ & 13 & PSUAMS-2339** & $3850 \pm 20$ & $2398-2233$ & $2457-2208$ & - & - & - \\
\hline
\end{tabular}

Wawrem', grave 386b; Samborzec, graves III and X; Święcice, grave 5 and Złota 'Grodzisko II', grave 173 (all sites in Sandomierz county; Budziszewski/ Wtodarczak 2010). In grave 5, artefacts made of boar or pig canine and awl were also found. For grave 2 a date $3860 \pm 35$ BP (Poz-101085) from a fragment of the long bone diaphysis was obtained that can be referenced after calibration to $2454-2236 \mathrm{BC}(1 \sigma$; Fig. 3: A). A younger date was acquired for grave 5, that was $3790 \pm 35$ BP (Poz-101084), i. e. after calibration 2286-2146 BC (1 $\sigma$; Fig. 3: B). Dating was done from the rib of the deceased.

Older ${ }^{14} \mathrm{C}$ dates for graves of the Bell Beaker culture from the Małopolska Upland at sites in Samborzec and Sandomierz have been acquired using the conventional method in the radiocarbon laboratory in Kiev (cf. Budziszewski/Włodarczak 2010, 114, table 11). In recent years, radiocarbon signatures using the AMS method have also been obtained for selected graves from Samborzec and Pełczyska, Pińczów county (Table 1; Olalde et al. 2018; Rudnicki/Włodarczak 2010). Dating for Samborzec shows significant differences between two different laboratories - for example: grave 7: $3825 \pm 25 \mathrm{BP}$ (PSUAMS-2321; Olalde et al. 2018) and $3990 \pm 60$ BP (Ki-7926; Budziszewski/Włodarczak 2010, 114, table 11).

Signatures gained for two graves from Beradź fall within the AMS dating range acquired for graves from Samborzec and Pełczyska (Fig. 3: C). Moreover the sequence of dates enable to distinguish the compacted time horizon for these finds, situating them in the period of cultural transformations taking place in the Final Neolithic and the Early Bronze Age.

Modelling of dating in Oxcal program (Fig. 4; Bronk Ramsey 2017; Reimer et al. 2013) also indicates a fairly short period for inhabitation of the Bell Beaker communities in the Małopolska Upland, that with a probability of $95.4 \%$ refers to the years $2416-2211$, and with a probability of $68.2 \%$ to the years 2331-2241 (Fig. 4). In the first case, it can be synchronized with the end of the Corded Ware culture in the Małopolska Upland and the proto- and early phase of the Mierzanowice culture (Górski et al. 2013; Kadrow 1997; Kadrow/Machnik 1997). In the $68.2 \%$ range, it corresponds with only early phases of the Mierzanowice culture. The coexistence of the Corded Ware culture and the Bell Beaker culture are indicated by individual ${ }^{14} \mathrm{C}$ dating (see Szczepanek et al. 2018, table 1; Włodarczak 2017, fig. 6; 2018, 195, table 7) and some cups from phase IIIb decorated with zone ornamentation in the Corded Ware culture assemblages according to $P$. Włodarczak (2006, $115,116)$, i. e. Żuków, Sandomierz county, grave 3[4] (Jarosz/Włodarczak 2007). The new dates obtained for the Bell Beaker culture from the Małopolska Upland are consistent with those obtained for graves in Lower Silesia (Furmanek et al. 2015, 533-535).

Carbon $\left(\delta^{13} C\right)$ and nitrogen $\left(\delta^{15} N\right)$ stable isotope analyses were performed at the Isotope Dating and Environment Research Laboratory at the Institute of Geological Sciences of the Polish Academy of Sciences in Warsaw. Collagen for these analyses was earlier extracted for AMS ${ }^{14} \mathrm{C}$ dating in the Poznan Radiocarbon Laboratory. Stable isotope composition was determined using a Thermo Flash EA 1112HT elemental analyser connected to a Thermo Delta V Advantage isotope ratio mass spectrometer in a Continuous Flow system. Results of the stable carbon and nitrogen isotopes analyses are shown in Figure 5 (A) and are listed in Table 1. Individuals from Beradź were presented on the background of the Final Neolithic Corded Ware culture and the Mierzanowice culture individuals from south-eastern Poland (according to Werens et al. 2018a; 2018b; Jarosz/Szczepanek 2019; Linderholm et al. 2020). The human stable isotope values of individuals of the Corded Ware culture except some outliers vary within a narrow range: $\delta^{13} \mathrm{C}$ between -20.4 and $-19.3 \%$ and $\delta^{15} \mathrm{~N}$ from 10 to $12.2 \%$. Higher $\delta^{15} \mathrm{~N}$ signature $(13.5 \%$ and $14.5 \%$ ) of two outliers are result of breastfeeding 


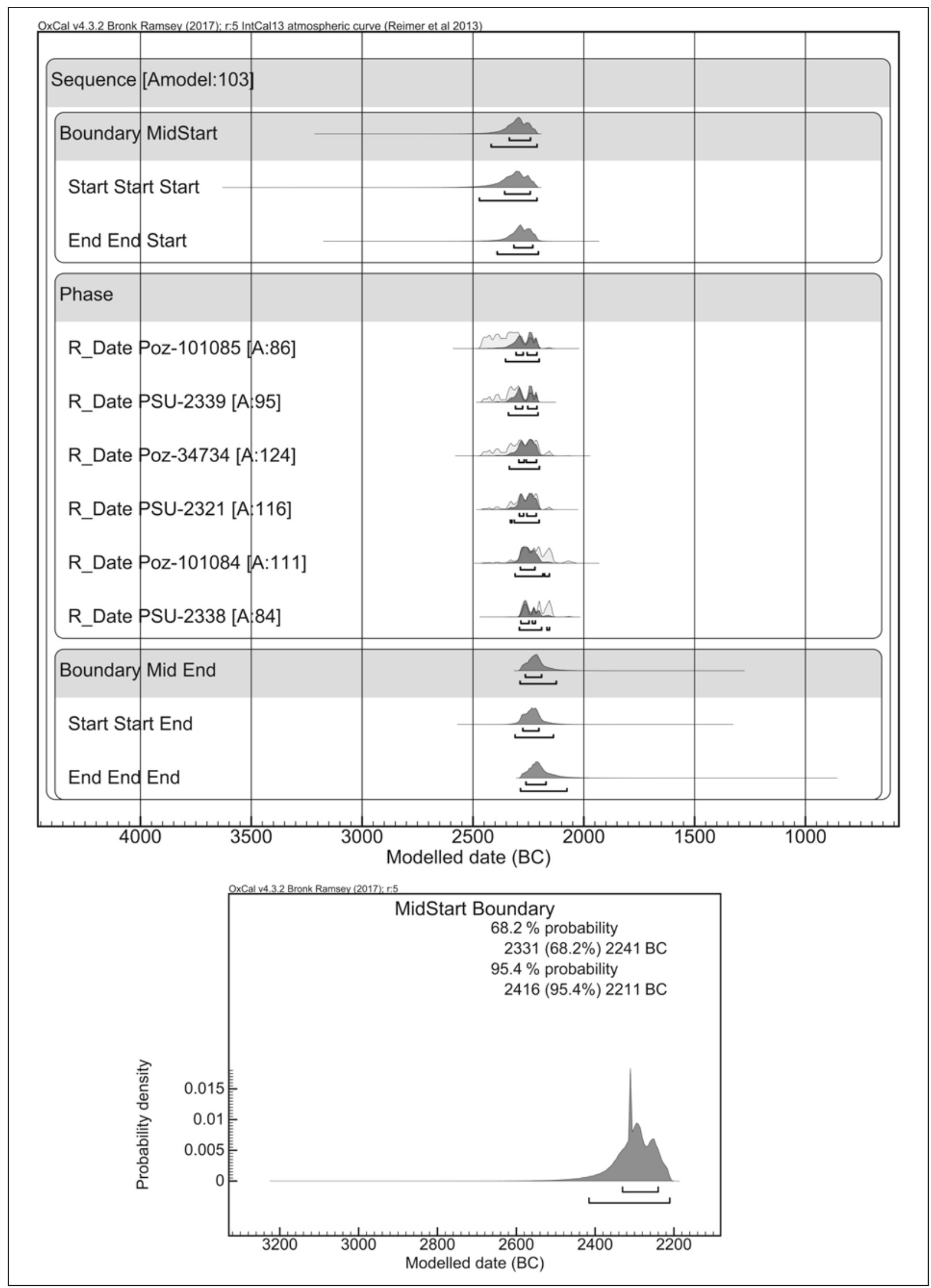

Fig. 4. Probability distribution of ${ }^{14} \mathrm{C}$ data of the Bell Beaker culture from Małopolska Upland (Trapezium). Edited by P. Jarosz. 


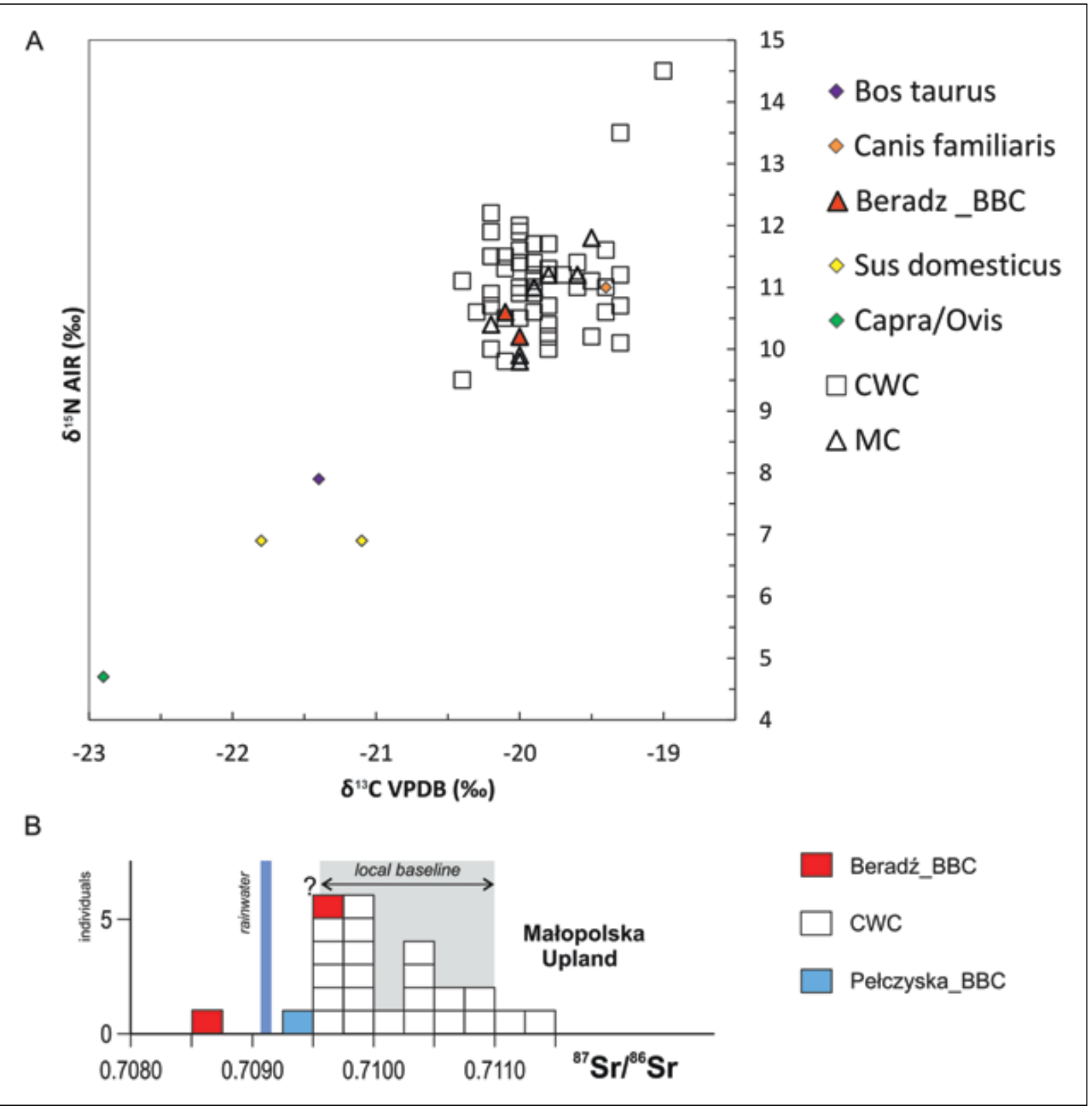

Fig. 5. Stable isotope results of $\delta^{13} \mathrm{C}$ and $\delta^{15} \mathrm{~N}$ in human and faunal remains from the Corded Ware, the Bell Beaker and the Mierzanowice culture from Małopolska Upland (A) and strontium isotope ratios $\left({ }^{87} \mathrm{Sr} /{ }^{86} \mathrm{Sr}\right)$ in human tooth enamel from the Bell Beaker culture sites at Beradź, Sandomierz county and Pełczyska, Pińczów county on the background of results acquired for the Corded Ware culture communities in Małopolska Upland (B; after Linderholm 2020 et al.; edited by A. Szczepanek).

effect and lower nitrogen values $(9.8 \%$ and $9.5 \%$ ) of two other outliers are probably an effect of their special diet possibly connected with their poor health condition (Szczepanek et al. 2018). The ranges for the Mierzanowice culture individuals are nearly similar $\left(\delta^{13} \mathrm{C}:-20.2\right.$ and $-19.5 \%$; $\delta^{15} \mathrm{~N}: 10.4$ to $11.8 \%$ ) with visible two outliers $\left(\delta^{15} \mathrm{~N}\right.$ : $9.9 \%$ and $9.8 \%$ o). Result acquired for individuals from Beradź are generally placed within these ranges but $\delta^{15} \mathrm{~N}$ values $(10.2 \%$ o and $10.6 \%$ ) create the lower part of them (Fig. 5: A). Domestic animals from the same region demonstrate depleted levels of both $\delta^{13} \mathrm{C}$ and $\delta^{15} \mathrm{~N}$ values. Acquired data are usual for humans living in a moderate climate with a terrestrial diet based on C3 plants, animal protein and possible riverine resources consumptions (Ambrose/Norr 1993; Mariotti et al. 1980).

The Sr isotope analyses were carried out in the Isotope Laboratory of the Adam Mickiewicz University 
at Poznań, Poland in dynamic collection mode on a Finnigan MAT 261 mass spectrometer (according to the procedure of Belka et al. 2018). The results of the strontium isotope investigations are shown in Figure 6 (B) and listed in Table 1. The strontium isotope signatures 0.709665 and 0.708667 acquired for individuals from Beradź differ from each other. The higher value is placed in lower part of the local baseline range established for individuals of the Corded Ware culture and being defined between 0.7095 and 0.7110 (Linderholm et al. 2020) whereas the lower value falls slightly below this local spectrum and suggest non-local origin of male individual. However, the differentiation of the local geology in the Małopolska Upland where the Maastrichtian (Upper Cretaceous) carbonates with Sr signatures around 0.7078 (McArthur et al. 2001) are locally exposed from under the cover of Pleistocene glacial deposits enable to extend this local baseline. Therefore it can be assumed that these individuals may have spent their childhood in this region but not in the same place.

Acquired radiocarbon dating in AMS technology and analysis of carbon $\left(\delta^{13} C\right)$ and nitrogen $\left(\delta^{15} N\right)$ and strontium $\left({ }^{87} \mathrm{Sr} /{ }^{\beta 6} \mathrm{Sr}\right)$ isotopes are very important for studies of the Bell Beaker culture in south-eastern Poland. The obtained dates confirm the possibility of including graves from southeastern Poland to the older or classical stage of the Bell Beaker culture de- velopment within its eastern province (Budziszewski) Wtodarczak 2010). According to the AMS signatures for the Bell Beaker culture graves (Table 1; Fig. 3) and the absolute chronology of this culture finds throughout Europe (Olalde et al. 2018), the dating of graves in the southeastern Poland can be restricted to the range of about $2400-2200 \mathrm{BC}$ that is consistent with earlier opinions of $M$. Rudnicki and P. Włodarczak (2010). Synchronization of the acquired data with the chronometry of cultures at the turn of the Neolithic and Bronze Age in southeastern Poland enable for considerations that the beginnings of the Bell Beaker culture are equal to or slightly younger than the materials of the late phase of the Kraków-Sandomierz group of Corded Ware culture (Szczepanek et al. 2018) and at the same time are little older than cemeteries and settlements of the earliest Mierzanowice culture phase (Górski et al. 2013; Jarosz/Szczepanek 2019; Kadrow/Machnik 1997, 26; Wtodarczak 2017; 2018).

Analysis of stable isotopes allowed for reconstruction that the paleodiet of buried individuals was typical for terrestrial environments based on C3 plants supplemented with animal protein. It was also possible to found that the female buried in grave 2 from Beradź was local, while the male from grave 5 spent his childhood in the area where carbonate rocks with less radiogenic strontium signatures are present that is potentially available in some Małopolska Upland areas.

\section{LITERATURE}

Ambrose/Norr 1993 - S. H. Ambrose/L. Norr: Experimental evidence for the relationship of the carbon isotope ratios of whole diet and dietary protein to those of bone collagen and carbonate. In: J. B. Lambert/G. Grupe (eds.): Prehistoric human bone: Archaeology at the Molecular Level. Berlin - Heidelberg 1993, 1-37.

Belka et al. 2018 - Z. Belka/J. Dopieralska/A. Szczepanek/ P. Jarosz: Human mobility in the final eneolithic population of Święte, Jarosław district, south-eastern Poland. Evidence from strontium isotope data. Baltic-Pontic Studies 23, 2018, 246-258.

Bronk Ramsey 2017 - C. Bronk Ramsey: Methods for Summarizing Radiocarbon Datasets. Radiocarbon 59-2, 2017, 1809-1833.

Budziszewski/Włodarczak 2010 - J. Budziszewski/P. Włodarczak: Kultura pucharów dzwonowatych na Wyżynie Małopolskiej. Kraków 2010.

Dvořák 1992 - P. Dvořák: Die Gräberfelder der Glockenbecherkultur in Mähren I (Bez. Blansko, Brno-Mĕsto, Brno-Venkov). Katalog der Funde. Brno 1992.

Furmanek et al. 2015 - M. Furmanek/A. Hałuszko/ M. Mackiewicz/B. Myślecki: New data for research on the Bell Beaker Culture in Upper Silesia, Poland. In: H. Meller/H. Wolfgang Arz/R. Jung/R. Risch (Hrsg.): 2200 BC - Ein Klimasturz als Ursache für den Zerfall der Al- ten Welt? 2200 BC = A climatic breakdown as a cause for the collapse of the old world? Tagungen des Landesmuseums für Vorgeschichte Halle. Band 12-2. Halle 2015, 523-536.

Górski et al. 2013 - J. Górski/P. Jarosz/K. Tunia/S. Wilk/ P. Włodarczak: New evidence on the absolute chronology of early Mierzanowice culture in south-eastern Poland. In: M. Bartelheim/J. Peška/J. Turek (eds.): From Copper to Bronze. Cultural and Social Transformations at the Turn of the $3^{\text {rd }} / 2^{\text {nd }}$ Millennia B.C. in Central Europe. Gewidmet PhDr. Václav Moucha, CSc. anlässlich seines 80. Geburtstages. Beiträge zur Ur- und Frühgeschichte Mitteleuropas 74. Langenweissbach 2013, 105-118.

Haduch 2010 - E. Haduch: Szczątki kostne ludności kultury pucharów dzwonowatych $\mathrm{z}$ terenów Małopolski. In: J. Budziszewski/P. Włodarczak (red.): Kultura pucharów dzwonowatych na Wyżynie Małopolskiej. Kraków 2010, 213-243.

Jarosz/Szczepanek 2019 - P. Jarosz/A. Szczepanek: Grób kultury mierzanowickiej z Jakuszowic na Płaskowyżu Proszowickim. In: M. Szmyt/P. Chachlikowski/J. Czebreszuk/M. Ignaczak/P. Makarowicz (red.): VIR BIMARIS. Od kujawskiego matecznika do stepów nadczarnomorskich. Studia z dziejów międzymorza bałtycko-pontyjskiego ofiarowane Profesorowi Aleksandrowi Kośko. Archaeologia Bimaris - Dyskusje 7. Poznań 2019, 281-293. 
Jarosz/Włodarczak 2007 - P. Jarosz/P. Włodarczak: Chronologia bezwzględna kultury ceramiki sznurowej w Polsce południowo-wschodniej oraz na Ukrainie. Przeglad Archeologiczny 55, 2007, 71-108.

Kadrow 1997 - S. Kadrow. Bemerkungen zur Chronologie der Frühbronzezeit in Kleinpolen und in der Slowakei. In: C. Becker/M.-L. Dunkelmann/C. MetznerNebelsick/H. Peter-Röcher/M. Roeder/B. Teržan (Hrsg.): Chronos. Beiträge zur prähistorischen Archäologie zwischen Nord- und Südosteuropa. Festschrift für Bernhard Hänsel. Internationale Archäologie. Studia honoraria 1. Espelkamp 1997, 229-235.

Kadrow/Machnik 1997 -S. Kadrow/J. Machnik: Kultura mierzanowicka. Chronologia, taksonomia i rozwój przestrzenny. Prace Komisji Archeologicznej 29. Kraków 1997.

Linderholm et al. 2020 - A. Linderholm/G. M. Kilınç/ A. Szczepanek/P. Włodarczak/P. Jarosz/Z. Belka/ J. Dopieralska/K. Werens/J. Górski/M. Mazurek/ M. Hozer/M. Rybicka/M. Ostrowski/J. Bagińska/ W. Koman/R. Rodríguez-Varela/J. Storå/A. Götherström/M. Krzewińska: Corded Ware cultural complexity uncovered using genomic and isotopic analysis from south-eastern Poland. Scientific reports 10, 6885, 2020. DOI: https://doi.org/10.1038/s41598-020-63138-w

Mariotti et al. 1980 - A. Mariotti/D. Pierre/J. C. Vedy/ S. Bruckert/J. Guillemot: The abundance of natural nitrogen 15 in the organic matter of soils along an altitudinal gradient (Chablais, Haute Savoie, France). Catena 7/1, 1980, 293-300.

McArthur et al. 2001 - J. M. McArthur/R. Howarth/T. Bailey: Strontium isotope stratigraphy. LOWESS version 3. best fit to the marine Sr-isotope curve for 0-509 Ma and accompanying look-up table for deriving numerical age. The Journal of Geology 109, 2001, 155-170.

Olalde et al. 2018 - I. Olalde/S. Brace/M. E. Allentoft/I. Armit/ K. Kristiansen/T. Booth/N. Rohland/S. Mallick/A. Szécsényi-Nagy/A. Mittnik/E.Altena/M. Lipson/I. Lazaridis/ T. K. Harper/N. Patterson/N. Broomandkhoshbacht/ Y. Diekmann/Z. Faltyskova/D. Fernandes/M. Ferry/ E. Harney/P. de Knijff/M. Michel/ J. Oppenheimer/ K. Stewardson/A. Barclay/K. W. Alt/C. Liesau//P. Ríos/ C. Blasco/J. V. Miguel/R. M. García/A. A. Fernández/ E. Bánffy/M Bernabò-Brea/D. Billoin/C. Bonsall/ T. Allen/L. Büster/S. Carver/L. C. Navarro/O. E. Craig/ G. T. Cook/B. Cunliffe/A. Denaire/K. E. Dinwiddy/ N. Dodwell/M. Ernée/C. Evans/M. Kuchařík/J. F. Farré/ C. Fowler/M. Gazenbeek/R. G. Pena/M. Haber-Uriarte/ E. Haduch/G. Hey/N. Jowett/T. Kovles/K. Massy/ S. Pfrengle/P. Lefranc/O. Lemercier/A. Lefebvre/C. H. Martínez/V. G. Olmo/A. B. Ramírez/J. L. Maurandi/ T. Majó/J. I. McKinley/K. McSweeney/B. G. Mende/ A. Modi/G. Kulcsár/V. Kiss/A. Czene/R. Patay/ A. Endrődy/K. Köhler/T. Hajdu/T. Szeniczey/J. Dani/ Zs. Bernert/M. Hoole/O. Cheronet/D. Keating/ P. Velemínský/M. Dobeš/F. Candilio/F. Brown/ R. F. Fernández/A.-M. Herrero-Corral/S. Tusa/ E. Carnieri/L. Lentini/A. Valenti/A. Zanini/ C. Waddington/G. Delibes/E. Guerra-Doce/B. Neil/M. Brittain/M. Luke/R. Mortimer/ J. Desideri/M. Besse/G. Brücken/M. Furmanek/ A. Hałuszko/M. Mackiewicz/A. Rapiński/S. Leach/ I. Soriano/K. T. Lillios/J. L. Cardoso/M. P. Pearson/ P. Włodarczak/T. Douglas Price/P. Prieto/P.-J. Rey/ R. Risch/M. A. Rojo Guerra/A. Schmitt/J. Serralongue/
A. M. Silva/V. Smrčka/L. Vergnaud/J. Zilhão/ D. Caramelli/T. Higham/M. G. Thomas/ D. J. Kennett/H. Fokkens/V. Heyd/A. Sheridan/ K.-G. Sjögren/P. W. Stockhammer/J. Krause/ R. Pinhasi/W. Haak/I. Barnes/C. Lalueza-Fox/ D. Reich: TheBeaker phenomenon and the genomic transformation of northwest Europe. Nature 555, 2018, 190-196. DOI: https://doi.org/10.1038/nature25738

Reimer et al. 2013 - P. J. Reimer/E. Bard/A. Bayliss/J. W. Beck/P. G. Blackwell/C. Bronk Ramsey/P. M. Grootes/ T. P. Guilderson/H. Haflidason/I. Hajdas/C. Hatté/ T. J. Heaton/D. L. Hoffmann/A. G. Hogg/K. A. Hughen/ K. F. Kaiser/B. Kromer/S. W. Manning/M. Niu/ R. W. Reimer/D. A. Richards/E. M. Scott/J. R. Southon/ R. A. Staff/C. S. M. Turney/J. van der Plicht 2013: IntCal13 and Marine13 Radiocarbon Age Calibration Curves 0 - 50,000 Years cal BP. Radiocarbon 55, 2013, 1869-1887.

Rudnicki/Włodarczak 2010 - M. Rudnicki/P. Włodarczak: Graves of the Bell Beaker Culture at Pełczyska, Site 6, Pińczów district/Groby kultury pucharów dzwonowatych ze stanowiska 6 w Pełczyskach, pow. pińczowski. Sprawozdania Archeologiczne 62, 2010, 353-372.

Ryan et al. 2018 - J. Ryan/J. Desideri/M. Besse: Bell Beaker Archers: Warriors or an Ideology? In: J. Kleijne/ M. Furholt/J. Müller (eds.): Think global, act local! Bell Beakers in Europe. Journal of Neolithic Archaeology. Special Issue 4, 2018, 97-122.

Sangmeister 1974 - E. Sangmeister: Zwei Neufunde der Glockenbecherkultur in Baden-Württemberg. Ein Beitrag zur Klassifizierung der Armschutzplatten in Mitteleuropa. Fundberichte aus Baden-Württemberg 1, 1974, 103-156.

Szczepanek et al. 2018 - A. Szczepanek/Z. Belka/ P. Jarosz/ Ł. Pospieszny/J. Dopieralska/K. M. Frei/ A. Rauba-Bukowska/K. Werens/J. Górski/M. Hozer/ M. Mazurek/P. Włodarczak: Understanding Final Neolithic communities in southeastern Poland. New insights on diet and mobility from isotopic data. PLoS ONE 13-12, 2018. DOI: https://doi/org10/1371/journal.pone.0207748

Werens et al. 2018a - K. Werens/A. Szczepanek/P. Jarosz: Light stable isotope analysis of diet in corded ware culture communities: Święte, Jarosław district, south-eastern Poland. Baltic-Pontic Studies 23, 2018, 229-245.

Werens et al. $2018 b$ - K. Werens/A. Szczepanek/P. Jarosz: Paleodieta przedstawicieli ludności kultury mierzanowickiej ze stanowisk 37 i 39 w Dobkowicach, pow. jarosławski. In: P. Jarosz (red.): Dobkowice, stanowiska 37 i 39, woj. podkarpackie. Osady kultury mierzanowickiej na Podgórzu Rzeszowskim. Via Archaeologica Ressoviensia 14. Rzeszów 2018, 161-168.

Włodrczak 2006 - P. Włodarczak: Kultura ceramiki sznurowej na Wyżynie Małopolskiej. Kraków 2006.

Włodarczak 2017 - P. Włodarczak: Battle-axes and beakers. The Final Eneolithic societies. In: P. Włodarczak (ed.): The Past Societies 2, 5500-2000 BC. Warszawa 2017, 275-336.

Włodarczak 2018 - P. Włodarczak: Chronometry of the Final Eneolithic Cemeteries at Święte, Jarosław District, from the Perspective of Cultural Relations Among Lesser Poland, Podolia and the North-Western Black Sea Region. Baltic-Pontic Studies 23, 2018, 178-212. 
Włodarczak/Kowalewska-Marszałek 1998 - P. Włodarczak/ H. Kowalewska-Marszałek: Datowanie bezwzględne zespołu kultury pucharów dzwonowatych z Sandomierza. Sprawozdania Archeologiczne 50, 1998, 55-82.
Żurowski 1932 - J. Żurowski: Pierwsze ślady kultury puharów dzwonowatych w Polsce. Wiadomości Archeologiczne 11, 1932, 117-168.

Manuscript accepted 18. 8. 2020

Translated by Anita Szczepanek

Súhrn preložila Anita Kozubová

dr Paweł Jarosz

Institute of Archaeology and Ethnology

dr hab. Elżbieta Haduch, prof. UJ

Department of Anthropology

Polish Academy of Sciences

Sławkowska 17

PL - 31-016 Kraków

Jagiellonian University

Gronostajowa 9

PL - 30-387 Kraków

ptjarosz@gmail.com

elzbieta.haduch@uj.edu.pl

dr hab. Anita Szczepanek

Institute of Archaeology and Ethnology

Polish Academy of Sciences

Sławkowska 17

PL - 31-016 Kraków

anita.szczepanek@uj.edu.pl

\title{
Nové poznatky ku kultúre zvoncovitých pohárov v Malopol’skej vysočine
}

\author{
Paweł Jarosz - Anita Szczepanek - Elżbieta Haduch
}

\author{
SÚHRN
}

Rádiouhlíkové datovanie a analýzy izotopov stroncia $\left(\mathrm{Sr}^{87} / \mathrm{Sr}^{86}\right)$, uhlíka $\left(\delta \mathrm{C}^{13}\right)$ a dusíka $\left(\delta \mathrm{N}^{15}\right)$ z hrobov 2 a 5 z Beradź v juhovýchodnom Pol’sku (Sandomierzsky okres) priniesli nové dôležité poznatky. Hodnoty izotopov uhlíka a dusíka ukazujú, že strava ženy (hrob 2) a muža (hrob 5) vo veku senilis bola typická pre suchozemské prostredie, jej základom bola rastlinná zložka (rastliny fotosyntézy C3), ktorá bola doplňovaná živočíšnymi bielkovinami. Hodnoty izotopov stroncia naznačujú miestny pôvod ženy pochovanej v hrobe 2 , zatial' čo muž pochovaný v hrobe 5 strávil detstvo mimo lokality Beradź a jej okolia, pravdepodobne ale niekde v Malopol'skej vysočine. Na základe rádiouhlíkového datovania je oba hroby z juhovýchodného Pol'ska možné priradit staršej alebo klasickej chronologickej fáze kultúry so zvoncovými pohármi a datovat' ich do rozpätia rokov 2400-2200 pred n. l. Na základe týchto zistení je počiatky kultúry so zvoncovými pohármi v juhovýchodnom Pol'sku možné synchronizovat’ alebo datovat’ o niečo neskôr ako materiály z neskorej fázy krakovsko-sandomierzskej skupiny kultúry so šnúrovou keramikou a zároveň sú juhovýchodopol'ské materiály kultúry so zvoncovými pohármi o niečo staršie ako pohrebiská a sídliská zo včasnej fázy mierzanovickej kultúry. 
